\title{
WHITBY JET JEWELS IN THE VICTORIAN AGE
}

\author{
Luís Mendonça de Carvalho, ${ }^{1,2}$ Francisca Maria Fernandes, ${ }^{3}$ \\ Maria de Fátima Nunes, ${ }^{3}$ and João Brigola ${ }^{3}$
}

\begin{abstract}
During the middle nineteenth century, jet obtained from Whitby (England) was sought after due to its dark black color and hardness. This fossilized plant material was used in mourning jewelry, and Whitby hard jet was regarded among the best for carving and bead making. Jet fashion was connected with Queen Victoria, whose long mourning period lasted for almost forty years.
\end{abstract}

Keywords: Whitby jet, Victorian traditions, mourning jewels

Jet can be found in many locations on Earth and it has been used since pre-historic times for beading and carving. Classic writers, including Aristotle and Pliny the Elder, wrote about its uses in medicine, and during the Medieval Age jet was prized for its black color, brilliancy and relative scarcity (Ward, 2008). It is a lustrous, opaque, amorphous, black mineraloid with an organic origin: decaying wood from trees related to species of contemporary Araucariaceae subjected to high pressures. This compression could have occurred in salt water (hard jet) or fresh water (soft jet) and jet microstructure still resembles some morphological features of wood, namely the wood vessels. The Mohs hardness of Whitby jet is around 4 and when rubbed against unglazed porcelain it leaves a ginger-brown streak; if touched with a hot needle, jet emits an odor similar to coal (Muller, 2003; Manutchehr-Danai, 2005).

The trees that were the organic source of Whitby jet lived during the Middle Jurassic (175Ma-161Ma) when the British Isles were located further south, in the area close to the present day Iberian Peninsula. The decaying Araucariaceae $\log$ s must have formed a significant part of the plant debris taken by river streams to the sea, where they became embedded in the thick sedimentary layers. They were later submitted to huge pressures from the increasing sedimentary layers, causing the dispersal of some decaying sections but leaving the more resistant ones that became hard jet. Whitby jet occurs in compact lumps of variable size, usually with a very dark black color. It was especially prized due to the absence of cracks and inclusions from other minerals, such as pyrite. It collected from beaches after sea storms eroded the jet deposits located in the shoreline but also came from small-scale mining (this began around 1840 and stopped in the early 1920's) (Muller, 2003; Ward, 2008; Woodcock and Strachan, 2012).

During the Roman occupation of England, jet from the region of Eboracum (modern York) was already being traded within the empire but only in the nineteenth century were jet deposits exploited on a larger scale in response to a growing interest for semi-precious black stones. The first Whitby jet workshop dates back to 1808 and was established with the assistance of a retired naval officer who realized the potential profits that could be made after seeing some items created by local turners. The new British railway network facilitated the jet trade and the growing seaside holiday season brought

This research was sponsored by FCT-Portuguese Science Agency TDC/HIS-HCT/111048/2009.

We are grateful to Her Majesty Queen Elizabeth II for the permission to use the excerpt from Queen Victoria's diary and Pamela Clark (Royal Archives, Windsor Castle).

${ }^{1}$ Museu Botânico, Instituto Politécnico de Beja, Rua Pedro Soares, 7800-295 Beja, Portugal

${ }^{2}$ Author for correspondence: museu@ipbeja.pt

${ }^{3}$ Centro de Estudos de História e Filosofia da Ciência, Universidade de Évora, Largo do Marquês de Marialva, 8, 7000-554 Évora, Portugal. 
many visitors to Whitby, who could eventually buy the locally produced jewels. The 1851 Great Exhibition was a venue that did much to introduce Whitby jet to the world and some lapidaries received auspicious orders from the European nobility, increasing the prestige of jet. By 1872 , jet trade was well established in Whitby with around two hundred workshops, and fourteen hundred men, women and children engaged in jet trade (Fig. 1) (Bower, 1873; McMillan, 1992). The best Whitby jewels were commonly made of hard jet but soft jet was occasionally used for carvings, these were then set into large cabochons made from hard jet. In the decade of 1870 , as jet jewels reached international markets and local deposits did not respond to the demand, local and imported jet of lower quality began to be used. This may have been one of the reasons for the decline of the industry, although other factors, both social and economic, were connected with the rapid decline of jet in the 1880's (Kendall, 1974; Ward, 2008).

\section{Victorian JET JeWELS}

The Victorian jet jewels were larger because this was required by mid-nineteenth century fashion but they were at the same time lighter than other black semi-precious stones. Although jet is easy to carve, it is difficult to create details without breaking it. The best and bigger Whitby jet pieces were carved into cameos, pendants and other prized pieces while smaller or less valuable lumps were used for beads (Fig. 2). Whitby connections with Queen Victoria date back as early as 1850, when Thomas Andrews of New Quay, advertised himself as Jet-Ornament Maker to Her Majesty (McMillan, 1992; Muller, 2003; Ward, 2008). When Prince Albert died, in 1861, the Queen entered into a long mourning period during which only jet jewels were worn at the court. People followed the court fashion and this gave rise to a new etiquette code in which only jet jewels were seen as appropriated for mourning (Fig. 3). When Queen Victoria celebrated her Golden Jubilee (1887) she relaxed her mourning and fashion changed. At the same time, less expensive black pieces made with other materials became available and Whitby workers could not compete with them (Muller, 2003; Finlay, 2007). Much of the success of Whitby jet was also linked with the Victorian obsession with death and mourning and when these ceased to be fashionable, the industry declined. Nevertheless, as late as 1889, when King Luis of Portugal died, a maid of honor at Buckingham Palace wrote in a letter to her mother: "I am in despair about my clothes, no sooner have I rigged myself out with good tweeds than we are plunged into the deepest mourning for the king of Portugal, jet ornaments for six weeks! ... It is a lesson, never to buy anything but black" (Mallet and Mallet, 1968). By the end of the nineteenth century, long after jet has passed its height of popularity, Queen Victoria still used it, as she wrote in her diary (22nd July 1896): "I wore a black satin dress with embroideries \& jet, a lace veil of old point, \& diamond diadem \& ornaments" (Queen Victoria, unpublished manuscript).

\section{Literature Cited}

Bower, J. 1873. Whitby Jet and its Manufacture. J. Soc. Arts 22: 80-87.

Finlay, V. 2007. Jewels: A Secret History. Random House, New York.

Kendall, H. 1974. The History of Whitby Jet: Its Workers from Earliest Times. Whitby Literary and Philosophical Society, Whitby.

Mallet, M., And V. Mallet 1968. Life with Queen Victoria: Marie Mallet's Letters from Court 18871901. John Murray, London.

Manutchehr-Danai, M. 2005. Dictionary of Gems and Gemology. Springer-Verlag, Berlin Heidelberg.
McMillan, M. 1992. Whitby Jet Through the Years. Mabel McMillan, Whitby.

Muller, H. 2003. Jet Jewellery and Ornaments. Shire Publications, Buckinghamshire.

WARD, G. 2008. The Grove Encyclopedia of Materials and Techniques in Art. Oxford University Press, New York.

Woodcock, N., and R. Strachan 2012. Geological History of Britain and Ireland (2nd Edition). Wiley-Blackwell, Oxford. 

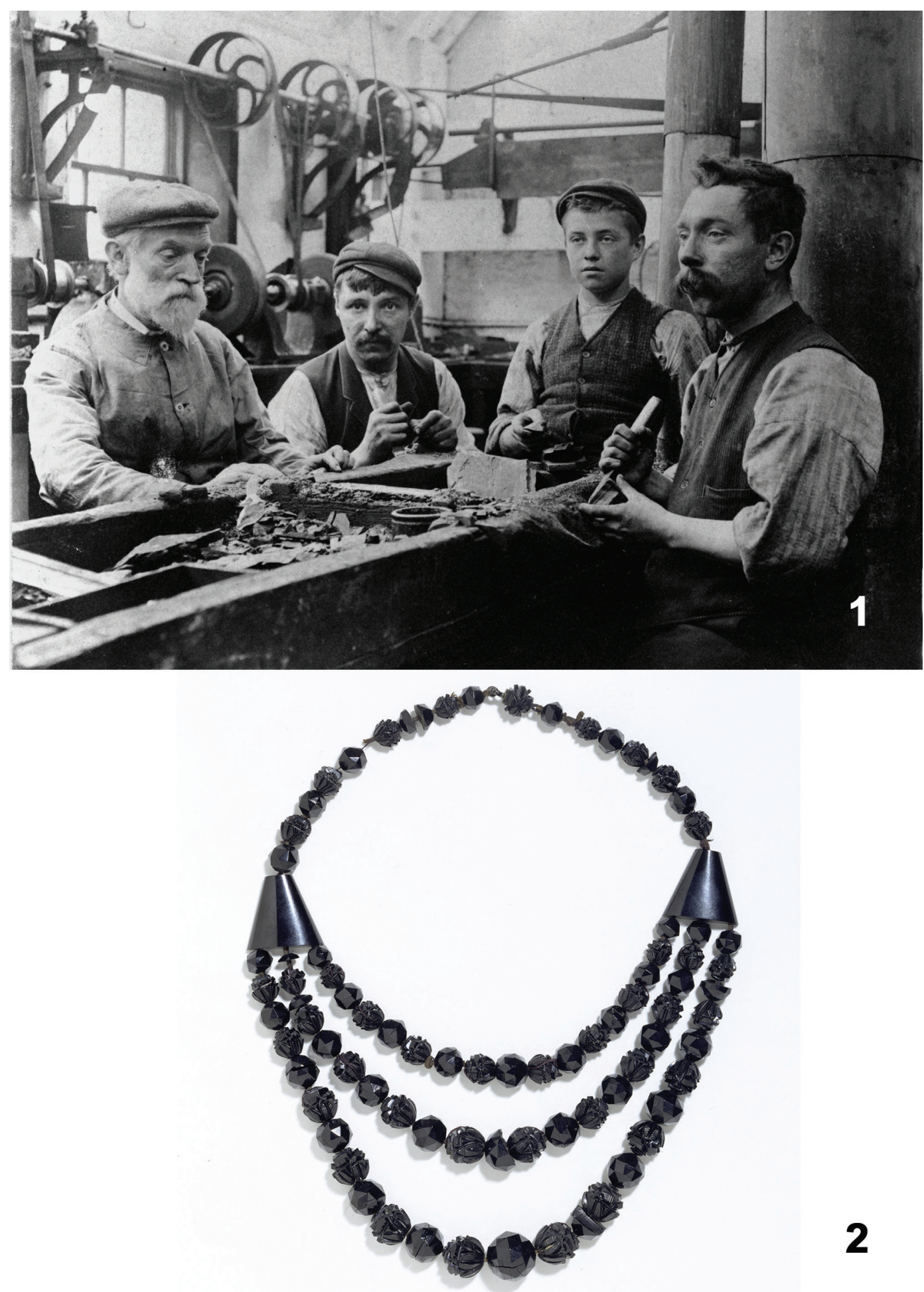

FIGURES 1-2. 1, Victorian jet workshop (Whitby Museum); 2, Whitby jet carved necklace (ca. 1875), Victoria and Albert Museum, London (M65-1974 given by Miss B.L. Edmundson). 


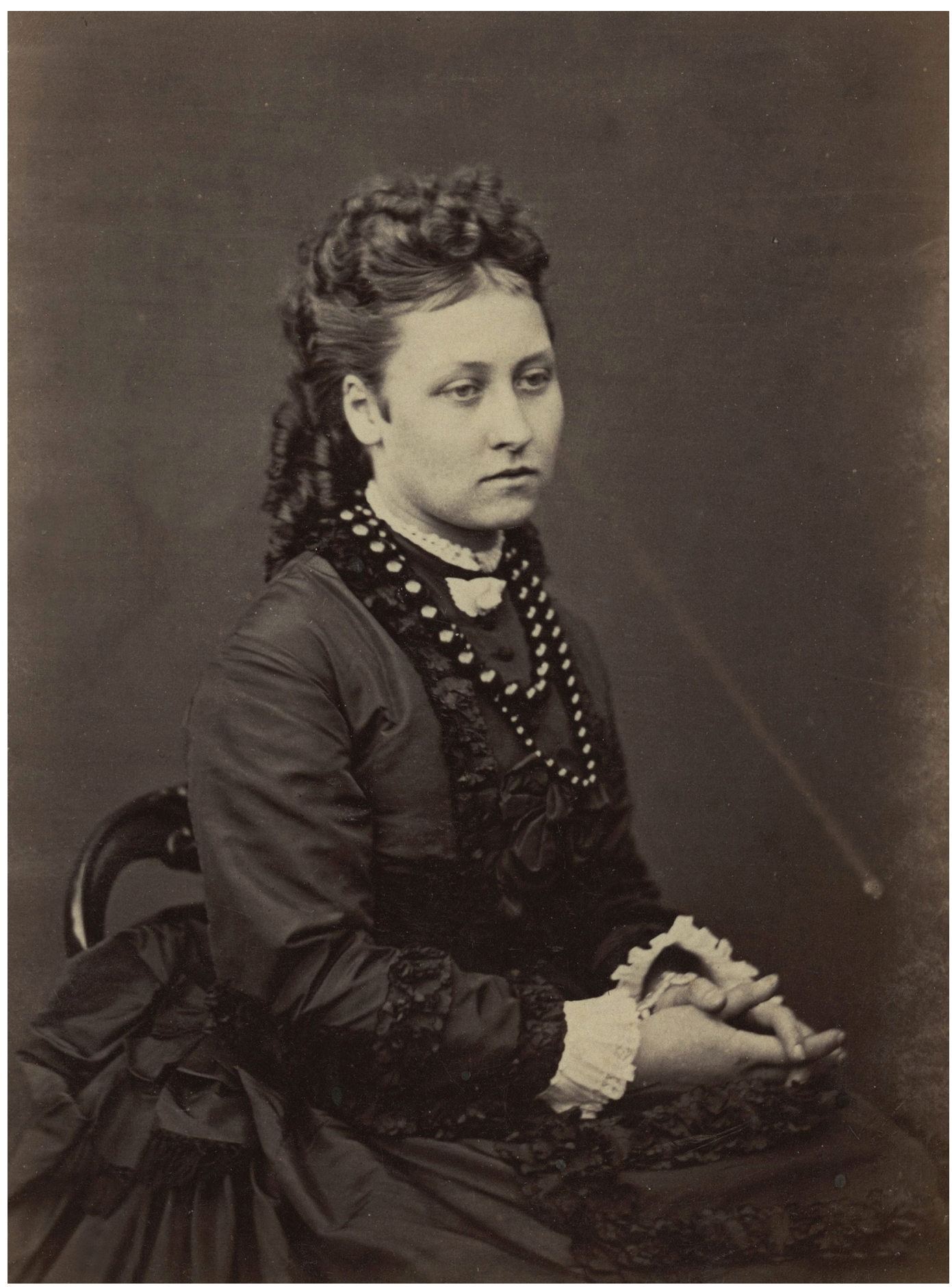

FIGURE 3. Princess Louise (1848-1939), daughter of Queen Victoria, wearing a double strand of jet beads (Credits). 